\title{
OBITUARY: DAVID DOWRICK (1935-2019)
}

\section{David Rhoades ${ }^{1}$ and Graeme McVerry ${ }^{2}$}

David Dowrick passed away peacefully in Tauranga on 13 September 2019 after several years of deteriorating health. He is survived by Gulielma, his wife of 47 years.

David made very significant contributions to engineering practice and earthquake research both in New Zealand and overseas. He was born on 28 March 1935 in Waipukurau. He graduated with a Bachelor of Civil Engineering from Auckland University in 1958. He worked for 28 years in engineering practice, starting as an assistant engineer at Babbage Shores \& Andrell in Auckland in 1958. In 1960 he moved to London and worked briefly at Token Construction, then for 20 years as a project engineer at Ove Arup \& Partners. In 1980 he returned to New Zealand and became a partner at Brickell Moss \& Partners in Wellington from 1980 to 1986 . This was followed by 18 years as an earthquake engineering researcher, initially in the Physics and Engineering Laboratory of the Department of Scientific and Industrial Research (DSIR) in Lower Hutt and then as a Principal Scientist at GNS Science from 1992 until his retirement in 2004. He was awarded a Doctor of Engineering degree from Auckland University for his research achievements in 2003. Following his official retirement, he moved to Tauranga and continued to be active in consulting and research until 2012. He was accorded Life Membership of the New Zealand Society for Earthquake Engineering in 2007.

David's consulting career involved many major earthquakeresistant design projects, including oil platform studies in the Maui gas field and the Gulf of Alaska, and the Ohaaki geothermal power station cooling tower. His non-seismic design projects include the roof of the Sydney Opera House, and the structural restoration of York Minster. For his paper on York Minster he was awarded the Institution of Civil Engineers' Telford Gold Medal. He advised the New Zealand Historic Places Trust on a variety of restoration projects.

Upon joining DSIR, David saw that earthquake hazard and risk research within the Department was uncoordinated and spread across a handful of independent Divisions. $\mathrm{He}$ was instrumental in forming an umbrella grouping known as Seismic Hazard Assessment New Zealand (SHANZ) through which information sharing and a loose coordination was maintained. SHANZ existed until the DSIR was dissolved and most of the main players came together in GNS Science.

After the Edgecumbe earthquake of 1987, David recognised an opportunity to obtain for the first time some hard data on damage to New Zealand buildings undergoing earthquake shaking. He set about with great determination to extract these data from insurance files and was untiring in his efforts to fill in gaps by site visits and personal contacts. In the end, working with Engineering Seismology colleagues, he managed to catalogue the damage and categorise the building-type of virtually every structure in the higher Modified Mercalli intensity zones, and so was able to relate the distribution of damage ratio to the intensity level for many classes of building and their contents. Subsequently, he led similar studies of damage in the Inangahua earthquake of 1968, the Hawke's Bay earthquake of 1931, and the Wairarapa earthquake of 1942. In the latter two cases, the relevant damage data had not been widely known to exist until David's enquiries uncovered it in library collections. David also directed much energy to the development of Modified Mercalli intensity relations for New Zealand, and the redefinition of the higher intensity levels to provide better consistency between levels based on structural and geotechnical damage such as liquefaction and landslides.

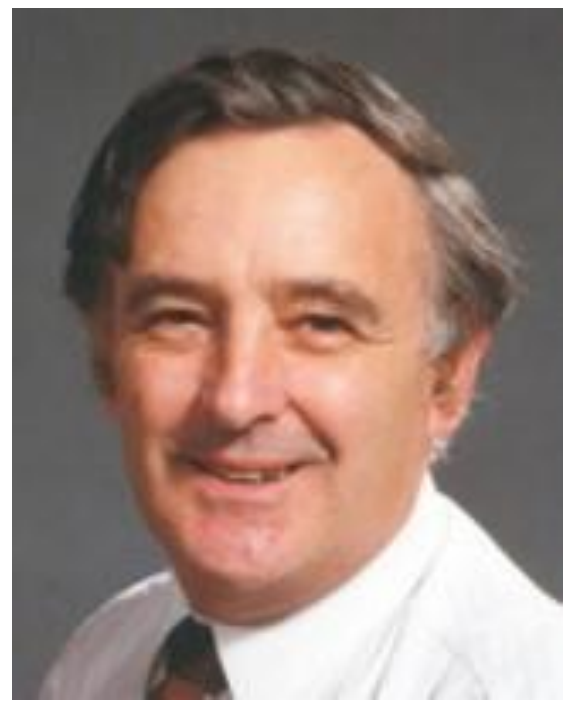

David Dowrick in 1995. Photo by Lloyd Homer, GNS Science.

David's research involved several successful collaborations with David Rhoades of GNS Science on his damage ratio and attenuation work, with Nick Ambraseys of Imperial College, London, and with Robin Spence of Cambridge University on damage ratios and allied topics. In maintaining the latter collaborations, David made several fruitful visits to the United Kingdom where, among other things, he accessed and personally interpreted antipodean records of large New Zealand earthquakes from the early instrumental period for his research on surface-wave magnitudes of New Zealand earthquakes.

David was a Fellow of the Institution of Civil Engineers, United Kingdom, and the Institution of Professional Engineers, New Zealand. He was a frequent contributor to the Bulletin of the NZSEE, in which he authored or co-authored more than 40 papers and was three times the recipient of the Otto Glogau Award - in 1996, 1998 and 2002. He was an author of many presentations at World, Pacific and New Zealand Earthquake Engineering Society conferences. He authored two books Earthquake Resistant Design published in 1977, with a second edition in 1987, and Earthquake Risk Reduction published in 2003 , with a second edition in 2009.

For leisure David enjoyed reading, walking and photography.

\footnotetext{
1 Geophysical Statistician, GNS Science, d.rhoades@gns.cri.nz

2 Retired (Ex Principal Scientist, GNS Science), graememcv@xtra.co.nz,(Life Member)
} 